\title{
AKTIVITAS ANTIBAKTERI EKSTRAK METANOL UMBI GADUNG (Dioscorea hispida Dennst.) TERHADAP BAKTERI PENYEBAB JERAWAT Propionibacterium acnes
}

\section{ANTIBACTERIAL ACTIVITY OF METHANOL EXTRACT OF GADUNG TUBERS (Dioscorea hispida Dennst.) AGAINST Propionibacterium acnes}

\author{
Susanti ${ }^{1 *}$, Richa Mardianingrum ${ }^{1}$ \\ ${ }^{1}$ Program Studi Farmasi Fakultas IImu Kesehatan Universitas Perjuangan Tasikmalaya \\ *Corresponding Author Email: susanti@unper.ac.id \\ DOI: http://dx.doi.org/10.47653/farm.v7i1.151
}

\begin{abstract}
ABSTRAK
Gadung (Dioscorea hispida Dennst.) adalah umbi liar yang banyak terdapat di wilayah Indonesia, khususnya di daerah Kabupaten Tasikmalaya, namun pemanfaatannya belum maksimal dibandingkan dengan tanaman umbi lainnya. Umbi gadung memiliki potensi besar dalam bidang farmasi, yaitu adanya senyawa fenol yang bermanfaat sebagai antimikroba. Tujuan penelitian adalah untuk mengetahui aktivitas antibakteri ekstrak metanol umbi gadung terhadap Propionibacterium acnes. Kadar fenol dianalisis menggunakan pereaksi Folin-Ciocalteu dan Spektrofotometer UV-Vis yang dinyatakan sebagai kadar fenol total (mg GAE/g ekstrak). Adapun uji aktivitas antibakteri dilakukan dengan metode disk diffusion. Hasil penelitian menunjukkan bahwa umbi Gadung mempunyai aktivitas antibakteri dengan diameter zona hambat 10,00 \pm 0.00 dengan kadar fenol total sebesar 127,5313 \pm 0,2133 mg GAE/gram untuk ekstrak daging umbi gadung dan 85,6719 \pm 0,1931 mg GAE/gram untuk ekstrak kulit umbi gadung. Meskipun diameter zona hambatnya masih lebih rendah dibandingkan kontrol positif, namun hal ini menunjukkan adanya potensi antibakteri yang cukup bagus dari umbi gadung.
\end{abstract}

Kata Kunci: Gadung, Fenol, Antibakteri, Jerawat

\section{ABSTRACT}

Gadung (Dioscorea hispida Dennst) is wild tuber that is widely available in Indonesia, but its utilization has not been optimalized compared to other tubers. Gadung have great potential for pharmaceutical field, especially the presence of phenol which is useul as antimicrobial. The aim of this study was to determine the antibacterial activity of methanol extracts of Gadung tubers against Propionibacterium acnes. Phenol contents were analyzed using Folin-Ciocalteu and UV-Vis Spectrophotometer expressed as total phenol content ( $\mathrm{mg} \mathrm{GAE} / \mathrm{g}$ extract). Antibacterial activity assay was carried out by disk diffusion method. The result showed that the extract has antibacterial activity with 10,00 $\pm 0,00$ $\mathrm{mm}$ diameter of inhibition zone. Total phenol content of tuber flesh is 127,5313 $\pm 0,2133 \mathrm{mg}$ GAE/ gram and for tuber peel extract is 85,6719 $\pm 0,1931 \mathrm{mg}$ GAE/gram extract. The activities is still lower than positive control, but this study shows the great antibacterial potential from gadung tubers.

Keywords: Gadung, Phenol, Antibacterial, Acne

\section{PENDAHULUAN}

Indonesia memiliki banyak jenis tanaman liar yang sebenarnya mempunyai potensi, khususnya dalam bidang farmasi. Salah satunya adalah gadung yang memiliki nama ilmiah Dioscorea hispida Dennst., merupakan jenis umbi liar yang kurang populer dibandingkan umbi lainnya memiliki kandungan sianida tinggi yang bisa menyebabkan keracunan jika pengolahannya tidak benar (Alma'arif dkk, 2012;
Kumoro dkk, 2011). Di wilayah Indonesia, Umbi gadung hanya dimanfaatkan sebagai bahan utama pembuatan keripik dan sebagai rodentisida untuk bidang pertanian (Posmaningsih dkk, 2014). Di negara lain, umbi gadung dimanfaatkan untuk pengobatan tradisional yaitu infeksi kulit umumnya disebabkan oleh bakteri Staphylococcus aureus (Miah et al, 2018). 
Dari hasil penelitian sebelumnya, umbi gadung memiliki kandungan senyawa fenol yang memiliki efek antibakteri dengan cara menghambat pertumbuhannya, merusak dinding sel, dan reaksi mutagenik. Selain itu fenol juga bersifat spektrum luas karena dapat menghambat pertumbuhan bakteri Gram positif dan bakteri Gram negatif (Miah et al, 2018). Salah satu contoh bakteri yang bersifat Gram positif adalah Propionibacterium acnes.

Hasil penelitian sebelumnya menunjukkan ekstrak metanol daging umbi gadung mempunyai kandungan fenol total sebanyak $287,50 \pm 0,71 \mathrm{mg} \mathrm{GAE} / \mathrm{mg}$ dan 102,513 $\pm 0,129$ mg GAE/gram (Miah et al, 2018; Susanti dkk, 2019). Masing-masing didapatkan dengan menggunakan metode ekstraksi yang berbeda. Senyawa fenol dari umbi gadung diketahui memiliki manfaat sebagai antibakteri, karena terbukti mampu menghambat pertumbuhan 12 mikroba patogen, salah satunya adalah Pseudomonas aeruginosa dengan diameter zona hambat $16,50 \pm 0,58 \mathrm{~mm}$ (Theerasin dan Baker, 2009). Namun belum ada penelitian mengenai aktivitas antibakteri terhadap bakteri penyebab jerawat, yaitu Propionibacterium acnes.

Dengan adanya data-data tersebut melatarbelakangi peneliti untuk melakukan ekstraksi senyawa fenol dari umbi gadung serta menguji aktivitasnya sebagai antibakteri terhadap bakteri penyebab jerawat, yaitu Propionibacterium acnes. Kadar fenol ditentukan berdasarkan reaksi oksidasi dengan reagen Folin-Ciocalteu disertai pengukuran absorbansi menggunakan spektrofotometer uvvis yang nilainya dinyatakan dengan $\mathrm{mg}$ GAE/gram ekstrak. Sedangkan aktivitas antibakteri terhadap Propionibacterium acnes dilakukan dengan metode disk diffusion.

Dengan mengetahui adanya aktivitas antibakteri terhadap bakteri penyebab jerawat dari umbi gadung, selanjutnya dapat menjadi dasar dalam memformulasikan umbi gadung menjadi suatu produk farmasi yang memiliki indikasi sebagai antijerawat dengan bahan dasar tanaman yang jarang dimanfaatkan oleh masyarakat.

\section{METODE PENELITIAN Alat}

Alat yang digunakan pada penelitian ini antara lain oven (Memmert), maserator, Spektrofotometer uv-vis (Agilent Technologies Cary 60), cawan petri dan inkubator,

\section{Bahan}

Bahan penelitian yang digunakan yaitu umbi gadung (Dioscorea hispida Dennst.), metanol p.a, pereaksi folin-ciocalteu, asam galat, natrium karbonat, Mueller Hinton Agar (OXOID), klindamisin,

\section{Pengumpulan dan Penyiapan Sampel}

Umbi Gadung (Dioscorea hispida Dennst.) berasal dari Kecamatan Karangnunggal, Kabupaten Tasikmalaya, Provinsi Jawa Barat. Determinasi tanaman dilakukan di SITH, Institut Teknologi Bandung. Umbi gadung dicuci, dipisahkan bagian kulit dan dagingnya, dirajang kemudian dikeringkan menggunakan oven pada suhu $40^{\circ} \mathrm{C}$. Selanjutnya dibuat menjadi serbuk simplisia.

\section{Ekstraksi}

Serbuk kulit umbi sebanyak 100 gram diekstraksi dengan metode maserasi pada suhu ruangan. Pelarut yang digunakan adalah metanol $60 \%$ dan air sebanyak $500 \mathrm{~mL}$. Lama ekstraksi adalah 48 jam. Ekstrak yang diperoleh kemudian difiltrasi dan dipekatkan menggunakan rotary evaporator. Ekstrak kental ditimbang dan kemudian dilarutkan dalam 20 $\mathrm{mL}$ metanol $60 \%$. Serbuk daging umbi diperlakukan dengan cara yang sama.

\section{Analisis Kadar Fenol Total}

Kadar fenol total ekstrak ditentukan dengan pereaksi Folin-Ciocalteu (Miah et al, 2018). Larutan standar asam galat dibuat variasi konsentrasi dari 60, 80, 100, 120 dan 140 $\mu \mathrm{gram} / \mathrm{mL}$. Sebanyak $0,5 \mathrm{~mL}$ asam galat dicampur dengan $2 \mathrm{~mL} \mathrm{Na} \mathrm{CO}_{3}(7,5 \% \mathrm{~b} / \mathrm{v})$ dan 2,5 $\mathrm{mL}$ pereaksi Folin-Ciocalteu. Kemudian sebanyak $10 \mathrm{mg}$ ekstrak dicampur dengan $5 \mathrm{~mL}$ metanol dan $0,5 \mathrm{~mL}$ dari campuran ekstrakmetanol dicampur dengan $2,5 \mathrm{~mL}$ pereaksi Folin-Ciocalteu dan $2 \mathrm{~mL}$ larutan $\mathrm{Na}_{2} \mathrm{CO}_{3}$. Setelah dilakukan inkubasi, absorbansi diukur menggunakan spektrofotometer Uv-Vis pada panjang gelombang $760 \mathrm{~nm}$. Kurva standar dibuat berdasarkan nilai absorbansi terhadap konsentrasi asam galat. Kadar fenol total dinyatakan dengan mg GAE (Gallic Acid Equivalent) / gram ekstrak.

\section{Uji Aktivitas Antibakteri}

Uji aktivitas antibakteri dilakukan dengan metode disc diffusion terhadap bakteri Propionibacterium acnes. Ekstrak umbi gadung (dalam metanol 60\%) sebanyak $500 \mu \mathrm{\mu g}$ diteteskan pada disk kertas yang steril dengan 
diameter $6 \mathrm{~mm}$. Masing-masing disk diletakkan di atas media Mueller Hinton Agar (MHA) yang telah mengandung bakteri Propionibacterium acne. Sebagai kontrol negatif digunakan disk blanko dan antibiotik Klindamisin (30 $\mu \mathrm{g} /$ disk) sebagai kontrol positif. Preparat diinkubasi selama 24 jam pada suhu $37^{\circ} \mathrm{C}$. Diameter zona bening yang mengelilingi disk diukur sebagai zona hambat $(\mathrm{mm})$.

\section{HASIL DAN PEMBAHASAN Hasil Ekstraksi Umbi Gadung}

Teknik ekstraksi yang dilakukan adalah maserasi dengan menggunakan pelarut metanol $60 \%$ selama 48 jam (2 hari). Banyaknya serbuk simplisia umbi gadung baik bagian kulit maupun bagian daging masing-masing sebanyak 100 gram dalam $500 \mathrm{~mL}$ metanol. Ekstrak cair yang dihasilkan berwarna kuning jernih. Setelah dipekatkan didapatkan ekstrak kental sebanyak 2,54 gram untuk ekstrak daging gadung (rendemen: $2,54 \%$ ) dan sebanyak 16,36 gram untuk ekstrak kulit gadung (rendemen: 16,36\%).

Tabel 1. Hasil Perhitungan Persen Rendemen Ekstrak Metanol Umbi Gadung

\begin{tabular}{ccc}
\hline Nama Ekstrak & Berat Ekstrak Kental (gram) & Rendemen (\%) \\
\hline Daging Umbi Gadung & 2,54 & 2,54 \\
Kulit Umbi Gadung & 16,36 & 16,36 \\
\hline
\end{tabular}

Nilai persen rendemen diperoleh berdasarkan perbandingan berat akhir (berat ekstrak yang dihasilkan) dengan berat awal (berat simplisia yang digunakan) dikalikan $100 \%$ (Sani dkk, 2014). Nilai persen rendemen dapat menentukan waktu ekstraksi optimal untuk digunakan pada ekstraksi simplisia (Kristian dkk, 2016). Dari hasil perhitungan rendemen ekstrak secara keseluruhan, ekstrak yang memiliki rendemen paling besar adalah ekstrak kulit gadung.

\section{Analisis Kadar Fenol Total}

Analisis kadar fenol total dilakukan terhadap sampel ekstrak metanol daging dan kulit umbi gadung menggunakan spektrofotometer uvvisible. Kadar fenol total ekstrak umbi gadung ditentukan berdasarkan reaksi oksidasi dengan reagen Folin Ciocalteu yang berperan sebagai agen pengoksidasi (Theerasin dan Baker, 2009). Larutan standar asam galat standar dibuat variasi konsentrasi dari $60,80,100,120$ dan 140 ppm. Kurva asam galat sebagai larutan standar dibuat berdasarkan nilai absorbansi terhadap konsentrasi asam galat, dapat dilihat pada Gambar 1. Kadar senyawa fenol total dinyatakan dalam satuan mg GAE (Gallic Acid Equivalent) / gram ekstrak yang disajikan pada Tabel 3.

Tabel 2. Hasil Pengukuran Absorban Larutan Baku Asam Galat

\begin{tabular}{cc}
\hline Konsentrasi (ppm) & Nilai Absorban pada Panjang Gelombang \\
\hline $\mathbf{6 0}$ & 0,4046 \\
$\mathbf{8 0}$ & 0,5479 \\
$\mathbf{1 0 0}$ & 0,6883 \\
$\mathbf{1 2 0}$ & 0,7811 \\
$\mathbf{1 4 0}$ & 0,9254 \\
\hline
\end{tabular}

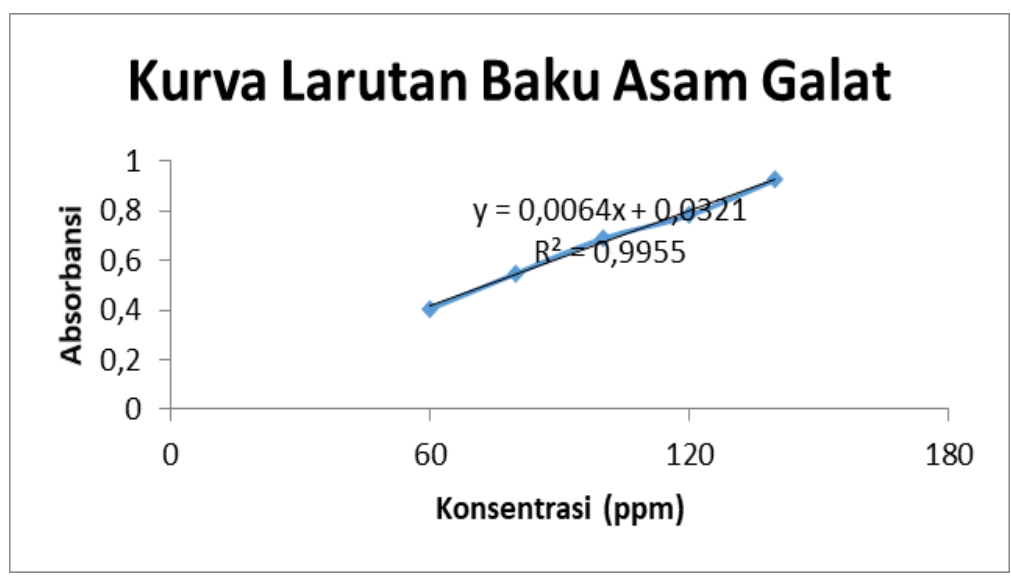


Gambar 1 Kurva Kalibrasi Larutan Baku Asam Galat

Tabel 3. Data Hasil Pengukuran Kadar Fenol Total Ekstrak Gadung

\begin{tabular}{cccc}
\hline Sampel & Nilai Absorban & $\begin{array}{c}\text { Kadar Fenol Total } \\
\text { (mg GAE/ gram ) }\end{array}$ & Persamaan Regresi \\
\hline Ekstrak Daging Gadung & $0,8483 \pm 0,0014$ & $127,5313 \pm 0,2133$ & $\mathrm{y}=0,0064 \mathrm{x}+0,0321$ \\
Ekstrak Kulit Gadung & $0,5804 \pm 0,0012$ & $85,6719 \pm 0,1931$ & \\
\hline
\end{tabular}

Kadar fenol total dari ekstrak metanol umbi gadung diperoleh menggunakan persamaan regresi $y=0,0064 x+0,0321, R^{2} 0,9955$, yang didapat dari kurva standar asam galat $(\mathrm{y}=$ absorban dan $\mathrm{x}=$ konsentrasi fenol dalam $\mathrm{mg}$ GAE/ gram ekstrak) (Theerasin dan Baker, 2009). Dari semua sampel ekstrak, kadar fenol tertinggi ditemukan pada sampel ekstrak daging umbi gadung.

\section{Uji Aktivitas Antibakteri}

Uji aktivitas antibakteri dilakukan pada ekstrak metanol umbi gadung terhadap bakteri Propionibacterium acnes. Dari hasil tahap penelitian sebelumnya, ekstrak metanol umbi gadung (kulit dan daging) mempunyai kandungan senyawa fenol. Senyawa fenol merupakan senyawa bioaktif yang paling banyak ditemukan di spesies Dioscorea. Pada daging umbi gadung (Dioscorea hispida Dennst.) memiliki kandungan senyawa fenol yang lebih tinggi dibandingkan dengan senyawa fenol pada bagian daun. Dan penelitian menunjukkan senyawa fenol pada umbi gadung memiliki efek antibakteri (Theerasin dan Baker, 2009). Senyawa fenol yang ditemukan pada umbi gadung diantaranya adalah asam kafeat, asam klorogenat (pada kulit umbi), phidroksibenzaldehid dan metal ester asam protokatekuat (pada daging umbi) (Miah dkk, 2018).

Aktivitas antibakteri diukur berdasarkan diameter zona hambatnya. Hasil pengukuran zona hambat bakteri dari ekstrak umbi gadung dapat dilihat pada Tabel 4.

Tabel 4. Data Hasil Pengukuran Diameter Zona Hambat

\begin{tabular}{cc}
\hline Sampel Uji & Diameter Zona Hambat (mm) \\
\hline Kontrol + & $14,67 \pm 1,15$ \\
Kontrol - & $0,00 \pm 0,00$ \\
Ekstrak Kulit Gadung & $10,00 \pm 0,00$ \\
Ekstrak Daging Gadung & $10,00 \pm 0,00$ \\
\hline
\end{tabular}

Kontrol positif yang digunakan adalah klindamisin yang merupakan antibiotik yang juga dapat digunakan untuk menghambat pertumbuhan bakteri Gram positif seperti Propionibacterium acnes. Dari hasil uji aktivitas antibakteri ekstrak methanol gadung, baik ekstrak kulit gadung maupun ekstrak daging gadung mempunyai aktivitas antibakteri terhadap Propionibacterium acnes, ditandai dengan adanya diameter zona hambat sebesar $10 \mathrm{~mm}$. Meskipun diameter zona hambatnya masih lebih rendah dibandingkan Klindamisin sebagai kontrol positif, namun hal ini menunjukkan adanya potensi antibakteri yang cukup bagus dari umbi gadung.

Secara umum, kemampuan antibakteri dari fenol adalah dengan cara denaturasi protein dan merusak membran sitoplasma sel. Ketidakstabilan dinding sel dan membran sitoplasma bakteri menyebabkan fungsi selnya terganggu. Gangguan integritas sitoplasma berakibat padalolosnya makromolekul, dan ion dari sel. Sel bakteri kehilangan bentuknya sehingga lisis (Lou dkk, 2011).

\section{KESIMPULAN}

Berdasarkan hasil penelitian menunjukkan bahwa ekstrak umbi Gadung mempunyai aktivitas antibakteri terhadap bakteri penyebab jerawat Propionibacterium acnes dengan diameter zona hambat $10,00 \pm 0.00$ dengan kadar fenol total sebesar 127,5313 $\pm 0,2133$ mg GAE/gram untuk ekstrak daging umbi gadung dan 85,6719 $\pm 0,1931 \mathrm{mg} \mathrm{GAE} /$ gram untuk ekstrak kulit umbi gadung.

\section{UCAPAN TERIMAKASIH}

Penulis mengucapkan terimakasih kepada LP2M Universitas Perjuangan Tasikmalaya atas hibah penelitian internal tahun 2019 yang mendanai peneltian ini.

\section{DAFTAR PUSTAKA}

Alma'arif, Ahmad Luthfi., dkk. 2012. Penghilangan Racun Asam Sianida ( $\mathrm{HCN})$ dalam Umbi Gadung Dengan 
Menggunakan Bahan Penyerap Abu. Jurnal Teknologi Kimia dan Industri, 1(1): 14-20.

Kristian, Jeremia., Sudaryanto Zain., Sarifah Nurjanah., Asri Widyasanti., Selly Hernesa Putri. 2016. Pengaruh Lama Ekstraksi terhadap Rendemen dan Mutu Minyak Bunga Melati Putih Menggunakan Metode Ekstraksi Pelarut Menguap (Solvent Extraction). Jurnal Teknotan, 10(2): 25286285

Kumoro, Andri Cahyo., Diah Susetyo Retnowati., Catarina Sri Budiyati. 2011. Removal of Cyanides from Gadung (Dioscorea hispida Dennst.) Tuber Chips using Leaching and Steaming Techniques. Journal of Applied Sciences Research, 7(12): 2140-2146.

Lou, Zaixiang., et al. 2011. Antibacterial Activity and Mechanism of Action of Chlorogenic Acid. Journal of Food Science, Vol. 76. No. 6.

Miah, Mohammad Mohasin., et al. 2018. In vitro Antioxidant, Antimicrobial, Membrane Stabilization and Thrombolytic Activities of Dioscorea hispida Dennst. European
Journal of Integrative Medicine, $19: 121$ 127.

Posmaningsih, D.A.A., I Nyoman Purna, I Wayan Sali. 2014. Efektivitas Pemanfaatan Umbi Gadung (Dioscorea hispida Dennst.) pada Umpan sebagai Rodentisida Nabati dalam Pengendalian Tikus. Jurnal Skala Husada, Vol. 11 No. 1: 79-85.

Sani, Robby Nasrul., Fithri Choirun Nisa., Ria Dewi Andriani., Jaya Mahar Maligan. 2014. Analisis Rendemen dan Skrining Fitokimia Ekstrak Etanol Mikroalga Laut Tetraselmis chuii. Jurnal Pangan dan Agroindustri, 2(2): 121-126.

Susanti., Richa Mardianingrum., Sri Yuliawati., Yuyun Febriani. 2019. Pengaruh Lama Ekstraksi terhadap Kadar Fenol Total Ekstrak Metanol Daging Umbi Gadung (Dioscorea hispida Dennst.). Journal of Pharmacopolium, Vol. 2 No. 3: 149-155.

Theerasin, Sudawadee., A.T. Baker. 2009. Analysis and Identification of phenolic compounds in Dioscorea hispida Dennst. Asian Journal of Food and Agro-Industry, 2(04) : 547-560. 